\title{
Les salines du Manga (Niger)
}

Pierre Gouletquer et Dorothea Kleinmann

\section{OpenEdition}

\section{Journals}

Édition électronique

URL : https://journals.openedition.org/tc/1001

DOI : $10.4000 /$ tc. 1001

ISSN : 1952-420X

Éditeur

Éditions de l'EHESS

Édition imprimée

Date de publication : 1 juin 1984

ISSN : 0248-6016

\section{Référence électronique}

Pierre Gouletquer et Dorothea Kleinmann, « Les salines du Manga (Niger) », Techniques \& Culture [En ligne], 3 | 1984, mis en ligne le 26 janvier 2006, consulté le 29 septembre 2022. URL : http:// journals.openedition.org/tc/1001; DOI : https://doi.org/10.4000/tc.1001

Ce document a été généré automatiquement le 29 septembre 2022.

Tous droits réservés 


\section{Les salines du Manga (Niger)}

Pierre Gouletquer et Dorothea Kleinmann 